\title{
KEPEMIMPINAN DEMOKRATIS KEPALA SEKOLAH
}

\author{
Maulana Akbar Sanjani \\ Dosen STKIP Budidaya Binjai
}

\begin{abstract}
ABSTRAK
Kepala Sekolah merupakan salah satu komponen pendidikan yang paling berperan dalam meningkatkan kualitas pendidikan. Kepala Sekolah adalah penanggung jawab atas penyelenggaraan pendidikan, administrasi sekolah, pembinaan tenaga pendidikan lainnya, pendayagunaan serta pemeliharaan sarana dan prasarana juga sebagai supervisor pada sekolah yang dipimpinnya. Jika dilihat dari syarat guru untuk menjadi Kepala Sekolah, Kepala Sekolah bisa dikatakan sebagai jenjang karier dari jabatan fungsional guru. Apabila seorang guru memiliki kompetensi sebagai Kepala Sekolah dan telah memenuhi persyaratan atau tes tertentu maka guru tersebut dapat memperoleh jabatan Kepala Sekolah. Kepemimpinan meliputi proses mempengaruhi dalam menentukan tujuan organisasi, memotivasi perilaku pengikut untuk mencapai tujuan, mempengaruhi untuk memperbaiki kelompok dan budayanya. Gaya kepemimpinan demokratis ditandai dengan pola perilaku tugas tinggi dan pola perilaku tenggang rasa tinggi. Kepala sekolah yang melakukan gaya kepemimpinan demokratis besar sekali perhatiannya, baik dalam upaya peningkatan kesejahteraan guru maupun pegawai. Berbeda dengan gaya kepemimpinan partisipatif yang lebih banyak mempercayakan kepada guru dan pegawai untuk mengorganisir pekerjaannya masing-masing. Dalam gaya kepemimpinan demokratis, kepala sekolah berperan aktif dalam menentukan tugas dan tanggung jawab masing-masing guru, dan tetap melakukan pengawasan dalam proporsi yang memadai.
\end{abstract}

kata kunci: kepemimpinan demokratis

\section{PENDAHULUAN}

Pendidikan pada dasarnya, harus berperan mengembangkan iklim belajar dan mengajar yang konstruktif bagi berkembangnya potensi kreatif peserta didik. Dalam hal ini kepala sekolah berperan penting dalam inovasi pendidikan, bagaimana membangun dan mengembangkan budaya kreatif, dan menciptakan academic athmosphere agar upayaupaya inovatif di sekolah menjadi budaya (kultur) dalam rangka profesionalisasi tenaga kependidikan. Penerapan kurikulum yang relevan dengan kondisi suatu sekolahagar tercipta guru yang butuh pembelajaran yang lebih rasional dan sesuai dengan kemampuan aspek peserta didik, pengajar dan sekolah. Selain itu, kreativitas akan membudaya apabila didasari komitmen yang kuat dari civitas sekolah. Kapabilitas kepemimpinan kepala sekolah diarahkan pada bagaimana membangun komitmen guru yang mampu menggerakkan daya kreativitas dan inovasi untuk senantiasa berusaha menambah pengetahuan dan meningkatkan ketrampilan khususnya yang langsung berkaitan dengan tugas profesionalnya. 
Kepala sekolah memiliki peranan yang sangat penting dalam menggerakkan, dan menyerasikan semua sumber daya pendidikan yang tersedia di sekolah dan mempergunakan sesuai kebutuhan. Artinya, kepemimpinan kepala sekolah merupa-kan salah satu faktor yang dapat mewujudkan visi, misi, tujuan dan sasaran sekolah melalui program-program yang dilaksanakan secara terencana dan bertahap. Kepala sekolah dituntut mempunyai kemampuan manajemen dan kepemimpinan yang memadai agar mampu mengambil inisiatif dan prakarsa untuk meningkatkan mutu pendidikan di sekolah. Kepemimpinan merupakan ruh yang menjadi pusat sumber gerak organisasi untuk mencapai tujuan. Kepemimpinan yang berkaitan dengan kepala sekolah dalam meningkatkan kesempatan mengadakan pertemuan secara efektif dengan para guru dalam situasi yang kondusif. Perilaku kepala sekolah harus dapat mendorong kinerja para guru dengan menunjukkan rasa bersahabat, dekat, dan penuh pertimbangan rerhadap para guru, baik sebagai individu maupun sebagai kelompok. Perilaku instrumental merupakan tugastugas yang diorientasikan dan secara langsung diklarifikasi dalam peranan.

Kepemimpinan kepala sekolah berkaitan dengan berbagai tugas dan fungsi yang harus diembannya dalam mewujudkan sekolah yang efektif, produktif, mandiri, dan akuntabel. Gaya kepemimpinan merupakan karakteristik seseorang untuk mempengaruhi orang lain atau organisasi, sehingga orang lain mau dan mampu bergerak serta meneladani sikap dan watak pribadinya kearah pencapaian tujuan. Gaya kepemimpinan adalah norma prilaku oleh seseorang pada saat itu mempengaruhi orang lain. Selanjutnya, Wahyudi (2012:123) menyata-kan bahwa: Gaya kepemimpinan yang diterapkan pada tingkat kematangan atau kedewasaan (mature) dewasaan bawahan dan tujuan yang ingin dicapai. Bawahan sebagai unsur penting yang terlibat dalam mencapai tujuan mempunyai perbedaan dalam hal kemampuan, kebutuhan dan kepribadian, sehingga pendekatan yang dilakukan pemimpin disesuaikan dengan tingkat kematangan bawahan. Kinerja kepemimpinan kepala sekolah dibatasi pada fungsi dan tugasnya dalam pelaksanaan penggunaan pengaruh, profesional, pemberdayaan, mobilitas, motivasi, pengarahan dan bimbingan, serta pembentukan komitmen. Kinerja manajemen kepala sekolah pada aspek keterbukaan, kemandirian, kerjasama, akuntanbilitas dan sustainbilitas. 


\section{KAJIAN TEORI}

\section{Definisi Kepemimpinan}

Kepemimpinan secara harfian berasal dari kata pimpin. Kata pimpin mengandung pengertian mengarahkan, membina atau mengatur, menuntun dan juga menunjukkan ataupun mempengaruhi. Pemimpin mempunyai tanggung jawab baik secara fisik maupun spiritual terhadap keberhasilan aktivitas kerja dari yang dipimpin, sehingga menjadi pemimpin itu tidak mudah dan tidak akan setiap orang mempunyai kesamaan di dalam menjalankan ke-pemimpinannya.

Kepemimpinan adalah hubungan antara seorang pemimpin dalam mempengaruhi orang lain untuk bekerja secara sadar dalam hubungan tugas untuk mencapai yang diinginkan pemimpin. Sedangkan Wirawan dalam Syaiful Sagala mengemukakan kepemimpinan adalah sebagai proses pemimpin menciptakan visi, mempengaruhi sikap, perilaku, pendapat, nilai-nilai, norma dan sebagainya dari pengikut untuk merealisasikan visi, (Syaiful, 2008). Menurut Sudarwan (2004: 56) kepemimpinan adalah setiap perbuatan yang dilakukan oleh individu atau kelompok untuk mengkoordinasi dan memberi arah kepada individu atau kelompok yang tergabung di dalam wadah tertentu untuk mencapai tujuan yang telah ditetapkan sebelumnya.

Gaya kepemimpinan adalah cara yang dipergunakan pemimpin dalam mempengaruhi para pengikutnya. Menurut Thoha (1995), gaya kepemimpinan merupakan norma perilaku yang digunakan seseorang pada saat orang tersebut mencoba mempengaruhi perilaku orang lain seperti yang ia lihat. Gaya kepemimpinan ialah polapola perilaku pemimpin yang digunakan untuk mempengaruhi aktivitas orang-orang yang dipimpin untuk mencapai tujuan dalam suatu situasi organisasinya dapat berubah bagaimana pemimpin mengembangkan program organisasinya, menegakkan disiplin yang sejalan dengan tata tertib yang telah dibuat, memperhatikan bawahannya dengan meningkatkan kesejahteraanya serta bagaimana pimpinan berkomunikasi dengan bawahannya.

Gaya kepemimpinan demokratis adalah kemampuan mempengaruhi orang lain agar bersedia bekerja sama untuk mencapai tujuan yang telah ditetapkan dengan cara berbagai kegiatan yang dilakukan ditentukan bersama pimpinan dan bawahan. Dalam melaksanakan tugasnya, ia mau menerima dan bahkan mengharapkan pendapat orang dan saran-saran 
dari kelompoknya. Kepemimpinan didefinisikan ke dalam ciri-ciri individual, kebiasan, cara mempengaruhi orang lain, interaksi, kedudukan dalam oragnisasi dan persepsi mengenai pengaruh yang sah dan menggerakan prilaku orang lain serta melakukan. Menurut Wahjosumidjo (2011:17) "Kepemimpinan diterjemahkan ke dalam istilah sifatsifat, perilaku pribadi, pengaruh terhadap orang lain, pola-pola interaksi, hubungan kerja sama antarperan, kedudukan dari satu jabatan administrasi, dan persepsi dari lain-lain tentang legitimasi pengaruh".

\section{PEMBAHASAN}

\section{Kepemimpinan Demokratis Kepala Sekolah}

Kepala Sekolah berasal dari dua kata yaitu "Kepala" dan "Sekolah" kata kepala dapat diartikan ketua atau pemimpin dalam suatu organisasi atau sebuah lembaga. Sedang sekolah adalah sebuah lembaga di mana menjadi tempat menerima dan memberi pelajaran. Jadi secara singkat Kepala Sekolah dapat diartikan pemimpin sekolah atau suatu lembaga di mana tempat menerima dan memberi pelajaran. Kepemimpinan kepala sekolah adalah cara atau usaha kepala sekolah dalam mempengaruhi, mendorong, membimbing, mengarahkan dan menggerakan guru, staf, siswa, orangtua siswa dan pihak lain yang terkait, untuk bekerja guna mencapai tujuan yang telah di tetapkan. Dengan kata lain bagaimana kepala sekolah untuk membuat orang lain bekerja untuk mencapai tujuan sekolah, (Depdikbud, 1999:11).

Kepala Sekolah merupakan salah satu komponen pendidikan yang paling berperan dalam meningkatkan kualitas pendidikan. Kepala Sekolah adalah penanggung jawab atas penyelenggaraan pendidikan, administrasi sekolah, pembinaan tenaga pendidikan lainnya, pendayagunaan serta pemeliharaan sarana dan prasarana juga sebagai supervisor pada sekolah yang dipimpinnya. Jika dilihat dari syarat guru untuk menjadi Kepala Sekolah, Kepala Sekolah bisa dikatakan sebagai jenjang karier dari jabatan fungsional guru. Apabila seorang guru memiliki kompetensi sebagai Kepala Sekolah dan telah memenuhi persyaratan atau tes tertentu maka guru tersebut dapat memperoleh jabatan Kepala Sekolah, (Mulyasa, 2007). Kepemimpinan kepala sekolah juga merupakan suatu kemampuan dan kesiapan kepala sekolah untuk mempengaruhi, membimbing, 
mengarahkan dan menggerakkan staf sekolah agar dapat bekerja secara efektif dalam rangka mencapai tujuan pendidikan dan pengajaran yang telah ditetapkan.

Agar sekolah dapat mencapai tujuannya secara etektif dan efesien, maka kepala sekolah harus melaksanakan fungsi-fungsi manajerial seperti perencanaan, pengorganisasian, pengarahan, pemberian motivasi, pelaksanaan, pengorganisasian pengendalian, evaluasi dan inovasi. Kepala Sekolah yang baik diharapkan akan membentuk pelaksanaan pembelajaran yang baik pula. Jika pembelajaran di sekolah baik tentunya akan menghasilkan prestasi yang baik pula baik siswanya maupun gurunya.

Demokratis adalah gaya kepemimpinan yang menekankan pada hubungan interpersonal yang baik. Ia mengharapkan para anggota organisasi berkembang sesuai potensi. Untuk itu pemimpin berupaya membimbing, mengarahkan dengan mempartisipasikan dalam kegiatan dan mengakui karya mereka secara proporsional. Pemimpin selalu memupuk rasa persaudaraan dan persatuan. Ia berusaha membangun semangat para anggota kelompok dalam menjalankan dan mengembangkan daya kerjanya. Pemimpin yang demokratis selalu berusaha menstimulasi anggotanya agar bekerja sesuai produktif untuk mencapai tujuan bersama, (Engkoswara dan Komariyah, 2010).

Kepala sekolah memiliki peranan yang sangat penting dalam menggerakkan, dan menyerasikan semua sumber daya pendidikan yang tersedia di sekolah dan mempergunakan sesuai kebutuhan. Artinya, kepemimpinan kepala sekolah merupa-kan salah satu faktor yang dapat mewujudkan visi, misi, tujuan dan sasaran sekolah melalui program-program yang dilaksanakan secara terencana dan bertahap. Kepala sekolah dituntut mempunyai kemampuan manajemen dan kepemimpinan yang memadai agar mampu mengambil inisiatif dan prakarsa untuk meningkatkan mutu pendidikan di sekolah, (Mulyasa, 2013:6)

Gaya kepemimpinan demokratis ditandai dengan pola perilaku tugas tinggi dan pola perilaku tenggang rasa tinggi. Kepala sekolah yang melakukan gaya kepemimpinan demokratis besar sekali perhatiannya, baik dalam upaya peningkatan kesejahteraan guru maupun pegawai. Berbeda dengan gaya kepemimpinan partisipatif yang lebih banyak mempercayakan kepada guru dan pegawai untuk mengorganisir pekerjaannya masingmasing. Dalam gaya kepemimpinan demokratis, kepala sekolah berperan aktif dalam menentukan tugas dan tanggung jawab masing-masing guru dan pegawai, dan tetap 
melakukan pengawasan dalam proporsi yang memadai. Namun demikian, kepala sekolah tidak melakukannya secara sepihak; artinya setiap keputusan yang diambil adalah merupakan hasil musyawarah.

Menjadi seorang kepala sekolah, tidak semudah yang dibayangkan. Apalagi tanggung jawab dari institusi untuk meningkatkan gairoh kinerja bawahannya (guru, staf, dan peserta didik) perlu inovasi dan kreasi dalam mengemban amanah tersebut. Adapun untuk meningkatkan kinerja yang apik dan relevan, seorang kepala sekolah perlu menanmkan nilai-nilai manajemen kepeimpinan dalam dirinya. Sehingga untuk meningkatkan kreatifitas guru dalam menididik peserta didik bisa terpacu dan semangat dalam menjalankan tugas dan fungsinya sebagai seorang guru bisa terlaksanakan dengann baik. Maka dari itu, kepala sekolah harus bersikap Luwes dalam hal Otonomi dan Inovasi (educator), Menyatu dalam Organisasi (administrator), Terikat Kepada Misi Sekolah (supervisor), Menghargai Staf (leader), Pemecahan Masalah Melalui Kerja Sama (inovator), dan Tertuju Pada Belajar Mengajar (motivator).

Menurut Sudarwan (2004:76) pemimpin demokratis memiliki ciri-ciri antara lain:

1) Beban kerja organisasi menjadi tanggung jawab bersama personalia organisasi itu.

2) Bawahan, oleh pemimpin dianggap sebagai komponen pelaksana secara integral harus diberi tugas dan tanggung jawab.

3) Disiplin akan tetapi tidak kaku dan memecahkan masalah secara bersama.

4) Kepercayaan tinggi terhadap bawahan dengan tidak melepaskan tanggung jawab pengawasan

5) Komunikasi dengan bawahan bersifat terbuka dan dua arah.

Kepala sekolah yang demokratis menyadari bahwa dirinya merupakan bagian dari kelompok, memiliki sifat terbuka, dan memberikan kesempatan kepada para tenaga kependidikan untuk ikut berperan aktif dalam membuat perencanaan, keputusan, serta menilai kinerjanya. Kepala sekolah yang demokratis memerankan diri sebagai pembimbing, pengarah, pemberi petunjuk, serta bantuan kepada para tenaga pendidikan. Oleh karena itu dalam rapat sekolah, kepala sekolah ikut melibatkan diri secara langsung dan membuka interaksi dengan tenaga pendidikan, serta mengikuti berbagai kegiatan rapat sekolah, (Mulyasa. 2003). 
Dalam suasana kerja kepemimpinan yang demokratis sebagian besar atau hampir seluruh "policy" dan keputusan-keputusan penting berasal dari dan disesuaikan dengan tuntutan-tuntutan situasi kelompok, dimana pemimpin bersama-sama dengan anggota kelompok ambil bagian secara aktif di dalam perumusan "policy" umum, keputusankeputusan penting dan program lembaga kerja itu, (Dirawat, 1983).

\section{Kriteria Pemimpinan Sekolah}

Dalam mewujudkan sekolah yang bermutu ini jelas membutuhkan kepemimpinan yang efektif. Kriteria kepala sekolah yang efektif ialah mampu menciptakan atmosfir kondusif bagi murid-murid untuk belajar para guru untuk terlibat dan berkembang secara personal dan profesional. Kriteria kepemimpinan kepala sekolah yang efektif adalah sebagai berikut:

1) Mampu memberdayakan pendidik dan tenaga kependidikan serta seluruh warga sekolah lainnya untuk mewujudkan proses pembelajaran yang berkualitas, lancar, dan produktif.

2) Dapat menyelesaikan tugas dan pekerjaan secara tepat waktu dan tepat sasaran.

3) Mampu menjalin hubungan yang harmonis dengan masyarakat sehingga dapat melibatkan mereka secara aktif dalam rangka mewujudkan visi dan misi sekolah serta tujuan pendidikan.

4) Mampu menerapkan prinsip kepemimpinan yang sesuai dengan tindakan kedewasaan pendidik dan tenaga kependidikan lain di sekolah.

5) Dapat bekerja secara kolaboratif dengan tim manajemen sekolah.

6) Dapat mewujudkan tujuan sekolah secara efektif, efisien, produktif dan akuntabel sesuai dengan ketentuan yang telah ditetapkan, (Mulyasa, 2011).

Kepemimpinan pendidikan yang efektif memberikan dasar dan menempatkan tujuan pada posisi penting untuk merubah norma-norma dalam program pembelajaran, meningkatkan produktivitas, dan mengembangkan pendekatan-pendekatan yang kreatif untuk mencapai hasil yang maksimal dari program institusi pendidikan, ruang pemberdayaan pemimpin pendidikan adalah terhindar dari intervensi birokrasi. Karena para birokrat dengan alasan menegakkan aturan selalu mengintervensi kebijakan sekolah, intervensi tersebut sesungguhnya lebih banyak merugikan daripada menguntungkan. Pemimpin satuan pendidikan yang efektif juga ditandai oleh kemampuannya menciptakan 
lingkungan belajar yang kondusif secara berkelanjutan, melakukan lompatan-lompatan berarti atas perubahan-perubahan melebihi apa yang ada dengan komitmen pengelolaan yang tinggi untuk memenuhi target yang ada dengan komitmen pengelolaan yang tinggi untuk memenuhi target dan tujuan pendidikan yang ditentukan sebelumnya.

\section{SIMPULAN}

Kepemimpinan meliputi proses mempengaruhi dalam menentukan tujuan organisasi, memotivasi perilaku pengikut untuk mencapai tujuan, mempengaruhi untuk memperbaiki kelompok dan budayanya. Sekolah adalah sebagai suatu komunitas pendidikan yang membutuhkan seorang pemimpin untuk mendayagunakan potensi yang ada dalam sekolah. Pada level ini, kepala sekolah sering dianggap satu atau identik, bahkan telah dikatakan bahwasanya wajah sekolah ada pada kepala sekolah. Peranan kepala sekolah di sini bukan hanya sebagai seorang akumulator, melainkan juga sebagai konseptor manajerial yang bertanggung jawab pada kontribusi masing-masing demi efektivitas dan efesiensi kelangsungan pendidikan. Jadi, kepala sekolah berperan sebagai manajer yang mengelola sekolah.

Gaya kepemimpinan demokratis ditandai dengan pola perilaku tugas tinggi dan pola perilaku tenggang rasa tinggi. Kepala sekolah yang melakukan gaya kepemimpinan demokratis besar sekali perhatiannya, baik dalam upaya peningkatan kesejahteraan guru maupun pegawai. Berbeda dengan gaya kepemimpinan partisipatif yang lebih banyak mempercayakan kepada guru dan pegawai untuk mengorganisir pekerjaannya masingmasing. Dalam gaya kepemimpinan demokratis, kepala sekolah berperan aktif dalam menentukan tugas dan tanggung jawab masing-masing guru dan pegawai, dan tetap melakukan pengawasan dalam proporsi yang memadai.

\section{REFERENSI}

Depdikbud. (1999). Supervisi Pendidikan (Materi Pelatihan Calon Kepala Sekolah). Dirjen: Dikdasmen.

Dirawat, dkk. (1983). Pengantar Kepemimpinan Pendidikan. Surabaya: Usaha Nasional. Engkoswara dan Komariyah,A. (2010). Administrasi Pendidikan. Bandung: Alfabeta. 
Mulyasa, E. (2003). Menjadi Kepala Sekolah Profesional: Dalam Konteks Menyukseskan $M B S$ dan KBK. Bandung: PT. Remaja Rosdakarya.

. (2007). Menjadi Guru Profesional Menciptakan Pembelajaran Kreatif dan Menyenangkan. Bandung: PT Remaja Rosdakarya.

. (2011). Manajemen dan Kepemimpinan Kepala Sekolah. Jakarta: Bumi Aksara.

. (2013). Pengembangan dan Implementasi Kurikulum 2013. Bandung: PT Remaja Rosdakarya

Sudarman, D. (2004). Motivasi Kepemimpinan dan Efektivitas Kelompok. Penerbit Rineka Cipta.

Syaiful, S. (2008). Administrasi Pendidikan Kontemporer. Bandung: Alfabeta.

Wahyudi, I. (2012). Mengejar Profesionalisme Guru Strategis Praktis Mewujudkan Citra Guru Profesionalis. Jakarta: Prestasi Jakarta.

Thoha, M. (1995). Perilaku Organisasi Konsep Dasar Dan Aplikasinya. Jakarta : Raja Grafindo Persada.

Wahjosumidjo (2011). Kepemimpinanan Kepala Sekolah. Jakarta: Rajagrafindo. 